\title{
The Ways to Maintain Sustainable China-Europe Block Train Operation
}

\author{
Babak Besharati ${ }^{1}$, Gansakh ${ }^{1}$, Feifei Liu ${ }^{1}$, Xiaomin Zhang ${ }^{1}$, Ming Xu ${ }^{1}$ \\ ${ }^{1}$ Donghua University, Shanghai, China \\ Correspondence: Donghua University, Shanghai, China.
}

Received: April 12, 2017

Accepted: May 30, 2017

Online Published: June 13, 2017

doi:10.11114/bms.v3i3.2490

URL: https://doi.org/10.11114/bms.v3i3.2490

\begin{abstract}
This paper intends to investigate the ways to maintain sustainable china-europe block train operation. Then it makes an analysis of the current situation of China-Europe Block Trains, and points out it's fast, booming development. Meanwhile, the paper collects some data about container rate that causes the loss of operation parties. To deal with such challenge, China's provincial governments provide subsides to maintain operation; however, it is looking for solutions to the problem, in case the challenges are sustainable.

It, also, has made some proposal for using empty return wagons and coantainer from Europe efficiently.
\end{abstract}

Keywords: China-Europe Block Train, Rate of FEU, Cost Challenges

\section{Introduction}

\subsection{Research Purpose}

This research would like to explain the ways to maintain sustainable china -Europe block train operation .First, it aims to study the current situation of China Europe block train and explore the booming development of china Europe block train then points out the causes to such fast development and also propose how to maintain this system to be a sustainable transportation. Particularly, this research tries to explain the changes that this rout is fainting in terms of cost and pricing and to propose how to use the empty return containers from Europe to be used efficiently.

\subsection{Focusing on China-Europe Logistic Solution}

Because of unbalanced trade relation between the two sides, in one hand, and commuting of China-Europe cargo Train, on other hand, this research would also explore the possibility to develop a business to use the railway to transport European products to China. Specially, if the market destination of European exportable products is the west part of China, this railway will balance the route.

\section{Literature Review}

In this part we explain the exciting train route between China and Europe, and its booming development. The existing changes of this route will be discussed in term of cost and price.

Since the main concern of this paper is running the governmental railway system utilizing subsidy which affects applying or not applying the railway, the relevant literature are mentioned accordingly.

\subsection{Three Railway Routes from China to Europe}

At the moment there are three railway routes (northern, middle and western) from China to Europe via Russia. Traditionally, the northern route is from Manzhouli City, the busiest land port in North China, through Russian Siberian railway to Moscow and connecting to European countries.

The second railway route is from Inner Mongolian's Erenhot City via Mongolia's Ulan Bator to Russian's Ulan-Ude to Siberian Railway.

The third one is the hottest route that has been discussed very much recently, which is from China's Longhai Railway and Lanxin Railway exiting from Alashankou Port to Astana Kazakhstan to Moscow.

All three routes are put in figure 1. 


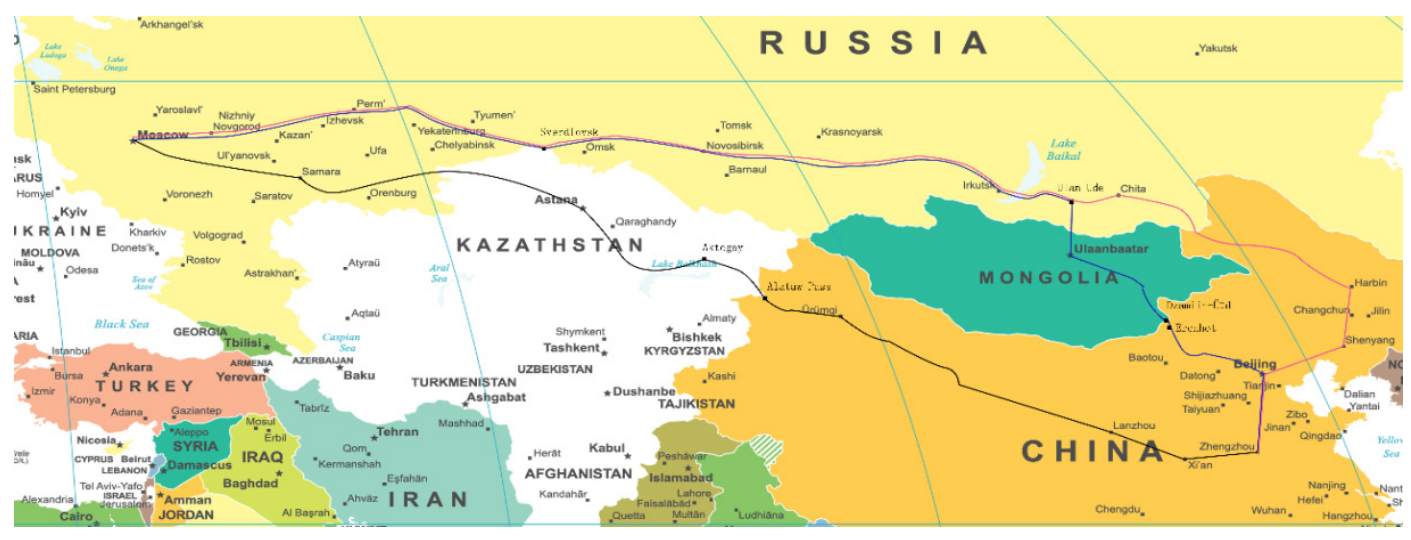

Figure 1. China's three railway routes to Moscow then to Europe

If all started from Zhengzhou, China's middle part, to Moscow, the three distances are 7,144 KM(Line one via Alashankou), 6,926 KM (Line two via Erenhort to Mongolian Ulan Bator) and 9,595 KM (Line Three via Manzhouli to Siberian Railway), respectively.

\subsection{Recent Booming Situation of China-Europe Railway Transportation}

\subsubsection{China-Europe Block Trains since 2011}

On March 19, 2011, first Block Train from Chongqing, China's western metropolis, was sent off to Duisburg Germany, which is regarded as "Yu-Xin-EU" Block Train, meaning from Chongqing through Xinjiang Uygur Autonomous Region to Europe. After that, from China to Europe (including middle east Region), such block trains have boomingly developed; there are more than 12 cities, such as Wuhan, Suzhou, Yiwu, and Zhengzhou which are named as "Han-Xin-Eu", Yi-Xin-Eu and Zheng-Xin-Eu, respectively. Until the end of 2016, the number of such Block trains have increased up to 1,702 (Huang, 2016).

We put all collected data about China-Europe block trains in table 1, to see the increased trend.

Table 1. China-Europe Block Trains Development

\begin{tabular}{|c|c|c|c|c|c|c|}
\hline Year & 2011 & 2012 & 2013 & 2014 & 2015 & 2016 \\
\hline $\begin{array}{l}\text { Regular Train } \\
\text { Numbers }\end{array}$ & 17 & 42 & 80 & 308 & 815 & 1702 \\
\hline Accumulation & 17 & 59 & 139 & 447 & 1262 & 2964 \\
\hline $\begin{array}{l}\text { Annual } \\
\text { Increase }\end{array}$ & - & $147 \%$ & $90 \%$ & $285 \%$ & $165 \%$ & $109 \%$ \\
\hline
\end{tabular}

In the above table, the data of 2011 and 2012 has come from Mr. Li Zhongyu's paper, which is published in Port Economy (He\& Li, 2016). Main data above is from the report of "Sino-Europe Block Train Accumulated to 1500", written by Mr. Peng Qian and Mr. Ma Jian, published in the People's Railway of China, April 13, 2016.

The report mentions that until April 6, 2016, the number of China-Europe block trains have accumulated to 1,500, the departure cities of which in China have increased to 12. The data for 2016 China-Europe Block Trains that has reached to 1702 has come from the annual report of Mr. Chen Dongfu, GM of China Railway Company on January 3, 2017. The services offered to customers are as follow: transportation document development, Custom clearance, inspection and quarantine, information follow up, consultation, loading and uploading, and port to port logistics. Daily transportation in China territory makes a distance of $1,300 \mathrm{~km}$ (Huang, 2016).

To see the increase trend of China-Europe Block Trains, the followings are listed:

From 1 block train to 500 ones, takes of 4 years to development,

- From 501 block trains to 1,000 ones, takes 7 months,

- From 1,001 block trains to 1,501 ones, takes 5 months,

- From 1,501 block trains to 1,800 ones, takes 3.5 months.

2.2.2 Why Such a Booming Trend Has Taken Place in China-Europe Block Trains?

First of all, this booming phenomenon is based on China's economic development demand, every inner and western provinces, such as Sichuan, Henan, Hunan, Yunnan, have the intentions to find a new mean of transportation to connect to the European countries for promoting their provincial businesses. Normally, from those provinces, their 
manufacturing goods need to be transported via railway to coast ports and shipped to Europe which takes more than 40 days. So, some companies with tight schedules will welcome new solution by taking the transportation service of China-Europe block Trains.

Second, Chinese President Xi Jinping has made speeches to develop One Belt and One Road as an initiatives to make cooperation between China and the Belt and Road Region countries, which stimulates the enthusiasm of Chinese provincial governments to develop such new ways for its provincial achievements. Among them, Chongqing Municipality Government took the first effort to develop block train to Duisburg Germany, which became a model to follow.

\subsection{The Problems Faced by China-Europe Block Train Users and Operators}

\subsubsection{Railway's Higher Costs vs Sea Transportation}

Currently, the clients should pay very high cost compared with the cost via sea way to take a block train to transport cargo from China to Europe. For example, the first Yu-Xin-EU block train to Duisburg Germany, one FEU (Forty Foot Equivalent Unit) costed USD 8,000-9,000, which was double double the cost for transportation via Yangtze River to transit in Port of Shanghai, per FEU 4,000 USD. From another block line called as Su-Man-Eu, the cost for a FEU is about USD7,500 (actually charge 6,000 USD with the subsides of 1,500 USD), whereas sea transportation via Shanghai to Hamburg is only 1,800 USD per FEU, that is less than one third of block train's cost.

\subsubsection{Unbalanced Freight Direction}

According to People's railway report, the block train of China to Europe (Hefei -Hanbao), which has started since June 2015, has recently been in normalized operation. However, among the 48 China Europe block trains from January to November, 2016, there has only been one return train carrying goods. We can come to the conclusion that the ratio of return trains carrying goods is extremely low, about 2 percent. This is a serious problem that is needed be solved urgently.

We know that the accumulation data in the year 2016, China-Europe block Train numbers are 1,702, but the information from GM of China Railway Company mentions that the return block train numbers are only 572 in the same year which makes about $33.6 \%$ of going to its European destinations. Moreover, from China Youth Daily report, since November 18 2014, the first block train to Madrid, Spain was sent on June 2016 from Yiwu, China's largest commodity whole sale city in Zhejiang province, by Yiwu. That made a total of sending off 58 block trains to European Cities, totally loaded 3,800 standard containers, whereas there are only 296 standard containers returned with the cargo (Li, 2015). The return rate is only about 8 percent of going to European destinations. Such unbalanced transportation situation has caused the costs of China-Europe block trains up reduced the confidence of parties involved in this new development of intercontinental cargo logistic businesses.

\section{Research Methodology}

We will do qualitative research and investigation on the railway route rate in different parts of China-Europe block train and compare them with each other.

Since this train way is not workable without national and local government support, we have to study Chinese local governments policies in subsidizing the route rate in current situation and predict their future behavior for subsidizing such routes which will play an important role in applying such a route for cargo transportation .One belt One road initiative has provided a suitable ground for local governments to use their power for extending the subsidy policy in some specific areas.

Considering the unbalanced situation in terms of trade between China and European union in one hand and train transportation in other, we have analyzed the possibility of using the return train from Europe to China as logistic and transportation means for specific cargoes which are preferably suitable to be transported by train.

\section{Research Finding}

\subsection{Railway Rate Decision Makers}

For the above three block trains of China cargo to Europe, concerning railway rates, there are different decision makers involved, including China, Russia, Mongolia, Kazakhstan, Belarus and European Union Nations. From our preliminary investigation, those railway decision makers have developed quite different rates, which combined into the whole cost for such transcontinental cargo services. Let us see the different situation in following.

\subsubsection{China's Railway Rate Decision Maker}

China Railway (CRCT) is China Railway Company's 100\% subsidiary, which is the container rate decision maker according to market supply and demand. Because of the different costs and demand faced by CRCT's provincial 
operation division, the rates are quite different in China's three lines to Europe. According to our investigation, currently the rate is roughly RMB $(680+2.754 \mathrm{X} \mathrm{KM})$, when they are used for the distance from Shanghai to Alashankou $(4,203$ $\mathrm{KM}$ ) which is equivalent to USD 0.42 per FEU per KM. When the mileage is less than the average per FEU Per KM the cost can be reduced to USD 0.65 .

\subsubsection{Commonwealth Independent States' Rate Decision Maker}

From the review of the related literature, the commonwealth Independent States' FEU rates are also different. For example, the railway line through Alashankou Pass to Kazakhstan is about USD 0.66-0.74per FEU per KM rate, whereas the railway line through Manzhouli pass to Russia is about 0.39 USD (Peng \& Ma, 2016) per FEU per KM. So, we see that in Commonwealth Independent States, railway rates are decided by different decision makers, which may have space to further reduction. The rate information is put into following table 2 for further discussion. The average rate in CIS regional be deduced from table 2, which is about half USD per KM per FEU.

Table 2. FEU Rate in Commonwealth Independent States (Unit: USD)

\section{Passing Kazakhstan Rate Passing Russia Rate}
$0.66-0.74$
0.39
$((0.66+0.74) / 2+0.39) / 2=0.545$

Average Rate in CIS

\subsubsection{European Union's Railway Rate Decision Maker}

From Phoenix Weekly (2015), the rate from Poland to Germany is about USD 0.97 per FEU per KM. The Germany and Czech Republic charged even more than Poland and other EU member countries.

\subsubsection{Comparison of Different Decision Makers of the Railway Lines from China to Europe}

Collecting all rate information in table 3, we can see the ratio for each provider, taking CIS countries' rate as a basis.

Table 3. The Rate information and Ratio of per KM per FEU (Unit: USD)

\begin{tabular}{llcl}
\hline Region & EU & Commonwealth Independent States & China \\
\hline Per FEU per KM & 0.97 & 0.545 & $(0.42+0.70) / 2=0.56$ \\
Ratio to CIS & 1.78 & 1 & 1.03 \\
\hline
\end{tabular}

Consulting some experts in Chinese railway companies, we noticed that the rate could be reduced with quantity discount as an example. Comparing to Russian rate 0.39 USD per FEU per KM, we think that all those rates are still having some reduction margin. Fortunately, from The XI International Rail Business Forum Strategic Partnership 1520 in Sochi ended on 3 June 2016, the Russia Railways President Oleg Belozerov, has delivered very long sight summary speech and said, "We need to move from competition to cooperation and coordinate our joint efforts" (Oleg, 2016). As a result, we hope that China can cooperate with Russia and Europe to lower the transportation rates.

\subsection{China Local Government's Subsidies to the China-Europe Block Trains}

As the logistic companies in China face high operation costs, they have asked local provincial governments to support such new transportation ways. The first subside event has been seen in Chongqing's Yu-Xin-Eu case, and then almost all provinces have taken the measures to offer subsides in different ways facilitate X-Xin-Eu block train operations. From Wang Yangkun (2015), some China-Europe block trains rate information, as well as subsidies in detail, are put into following table (table 4).

Table 4. Container Rate and Government Subsidies of China-Europe Block Trains (Unit: USD)

\begin{tabular}{|c|c|c|c|c|c|}
\hline NAME of Route & From-To & Distance(KM) & Rate & Days & SUBSIDIES \\
\hline YU XIN EU & $\begin{array}{l}\text { CHONG QING to Duisburg, } \\
\text { Germany }\end{array}$ & 11000 & 8900 & $15 \sim 17$ & $3500 \sim 4000$ \\
\hline HAN XIN EU & WU HAN to Chech, Poland & 10700 & 12000 & $15 \sim 17$ & $4000 \sim 5000$ \\
\hline $\begin{array}{l}\text { RONG EU Fast } \\
\text { Train }\end{array}$ & CHENG DU to Lodz, Poland & 9965 & 10290 & $12 \sim 14$ & $3000 \sim 3500$ \\
\hline ZHENG EU & $\begin{array}{l}\text { ZHENG ZHOU to Hamburg, } \\
\text { Germany }\end{array}$ & 10245 & 10500 & $16 \sim 18$ & $3000 \sim 7000$ \\
\hline SU MAN EU & SU ZHOU to Warsaw, Poland & 11200 & 7500 & $12 \sim 15$ & 1000 (has been canceled) \\
\hline YI XIN EU & YI WU to Madrid, Spain & 13052 & 10000 & 21 & $\begin{array}{l}\text { This is good case without } \\
\text { subsides. }\end{array}$ \\
\hline YING MAN EU & $\begin{array}{l}\text { YING KOU to Poland, Belarus } \\
\text { and Slovakia }\end{array}$ & 14000 & - & $12 \sim 13$ & - \\
\hline YU XIN EU & $\begin{array}{l}\text { CHONG QING to Duisburg, } \\
\text { Germany }\end{array}$ & 11000 & 8900 & $15 \sim 17$ & $3500 \sim 4000$ \\
\hline
\end{tabular}


From the above table, we can see that China provincial government's subsidy is varying from 0 to 7,000 USD per FEU in 2014. Why did such different situation happened? The reasonable explanation for this is that all these subsidies decisions are decided by Chinese local provincial governments. The author of the present paper would like to point out that China Railways realized that because so many provincial governments involved in this new transportation means development, which all use local name in such railway route, which caused unnecessary provincial region competition to collect cargo sources, and also caused chaotic situation to cooperation internationally. So in order to formulate unified image, China Railway Company in June 2016 announced that all those China-Europe Block Trains are renamed as "China Railway Express", previous name as X-Xin-Eu as Yu-Xin-EU, Han-Xin-EU, Yi-Xin-EU and Zheng-Xin-EU are stopped to use again.

From the above table, we also know that Henan Provincial Government offered extremely high subside to per FEU maxim to USD 7,000, while eastern provinces such as Jiangsu and Zhejiang province have not provided such subsidies, this kind of transportation means is more sustainable.

Based on our investigation about China-Europe Block Trains cases, we know that now government subsidies are normal cases, so for this research, we use subsidies' data in table 4 and get average per block train's government subsidies are about USD 3542, thinking about the trend to gradually reduce such subsidies, also consulted some managers in this industry, we estimate that USD 2,500 could be the average subsides for each sending off China FEU. According to the data in table 1, to the end of 2016, total block trains from China to Europe are 2,964, which is equivalent to 121,524 FEU (usually per block train takes about 41 FEU containers), so the total amount of government subsides could be as 303 million USD about RMB2.billion for the period of 2011 to 2016.

\subsection{European Union Trade with China}

China and Europe has developing trade relation within last decades and rent figures as came in table 5 shows that total trade in 2016 was more than 514 billion euro and export of Chinese products was more than import of European staff to china which balances was 174 billie euro in favor of china and trade between two sides has been increased with $4.2 \%$ growth rate within 2012-2016.

China was the first import partner of Europe and second partner of export for European union and totally china was the second commercial and trade partner of European union.

Table 5. Europe union trade with China, key figures (Unit: million euro)

\begin{tabular}{lcccccc}
\hline Indicator & Unit & Period & Imports & Exports & Total trade & Balance \\
\hline Last year & Mio euros & 2016 & 344,642 & 170,136 & 514,779 & $-174,506$ \\
$\begin{array}{l}\text { Rank as } \\
\text { partner }\end{array}$ & $\%$ & 2016 & 1 & 2 & 2 & \\
$\begin{array}{l}\text { Share in EU } \\
\text { trade }\end{array}$ & $\%$ & 2016 & 20.2 & 9.7 & 14.9 & \\
$\begin{array}{l}\text { Annual } \\
\text { growth rate }\end{array}$ & $\%$ & $2015-2016$ & -1.7 & -0.1 & \\
$\begin{array}{l}\text { Annual } \\
\text { average } \\
\text { growth rate }\end{array}$ & $\%$ & $2012-2016$ & 4.2 & 4.2 & \\
\hline Accordin & & & & & \\
\end{tabular}

According to the table 6, the main items which imported by Europe Union from china have been Machinery and appliances, Textiles and textile articles, miscellaneous manufactured articles, Base metals and articles thereof, products of the chemical or allied industries, and the main items which exported by Europe Union to china have been machinery and appliances, transport equipment, products of the chemical or allied industries, optical and photographic instruments, etc., as well as base metals and articles thereof. Figures indicate that the combination of export and import items from Europe to china and vice versa is not exactly alike and we can explore more potential items from Europe to be exported to china to fill the big balance gap between the two sides. 
Table 6. Europe union trade with China based on top main 5 HS section (Unit: million Euro)

\begin{tabular}{|c|c|c|c|c|c|}
\hline \multicolumn{3}{|c|}{ Imports 2016} & \multicolumn{3}{|l|}{ Exports 2016} \\
\hline Product & Value Mio $€$ & \% Total & Product & Value Mio $€$ & $\%$ Total \\
\hline $\begin{array}{l}\text { Machinery } \\
\text { and } \\
\text { appliances }\end{array}$ & 166,261 & 48.2 & $\begin{array}{l}\text { Machinery and } \\
\text { appliances }\end{array}$ & 51,826 & 30.5 \\
\hline $\begin{array}{l}\text { Textiles and } \\
\text { textile articles }\end{array}$ & 37,435 & 10.9 & $\begin{array}{l}\text { Transport } \\
\text { equipment }\end{array}$ & 40,214 & 23.6 \\
\hline $\begin{array}{l}\text { Miscellaneous } \\
\text { manufactured } \\
\text { articles }\end{array}$ & 32,267 & 9.4 & $\begin{array}{l}\text { Products of the } \\
\text { chemical or } \\
\text { allied industries }\end{array}$ & 17,619 & 10.4 \\
\hline $\begin{array}{l}\text { Base metals } \\
\text { and articles } \\
\text { thereof }\end{array}$ & 22,236 & 6.5 & $\begin{array}{l}\text { Optical and } \\
\text { photographic } \\
\text { instruments, etc }\end{array}$ & 11,255 & 6.6 \\
\hline $\begin{array}{l}\text { Products of } \\
\text { the chemical } \\
\text { or allied } \\
\text { industries }\end{array}$ & 14,501 & 4.2 & $\begin{array}{l}\text { Base metals and } \\
\text { articles thereof }\end{array}$ & 10,063 & 5.9 \\
\hline
\end{tabular}

If the trade items between the two regions are more deeply studied, more interesting information can be achieved as bellow:

According the table 7, the export of Live animals and animal products from Europe to china have been doubled during 2013-2016, the export of Foodstuffs, beverages, tobacco have become doubled comparing the similar period of time; however, the other main export items from Europe to china such as machinery and appliances, transport equipment, optical and photographic instruments, pearl, precious metals and articles thereof have not been increased considerably. The export of some items has even decreased including vegetable products, animal or vegetable fat and oil, raw hides and skins, as well as saddlery, base metals and articles thereof. 
Table 7. Trade flows by Europe union and China HS section 2013 - 2016 (unit: million euro)

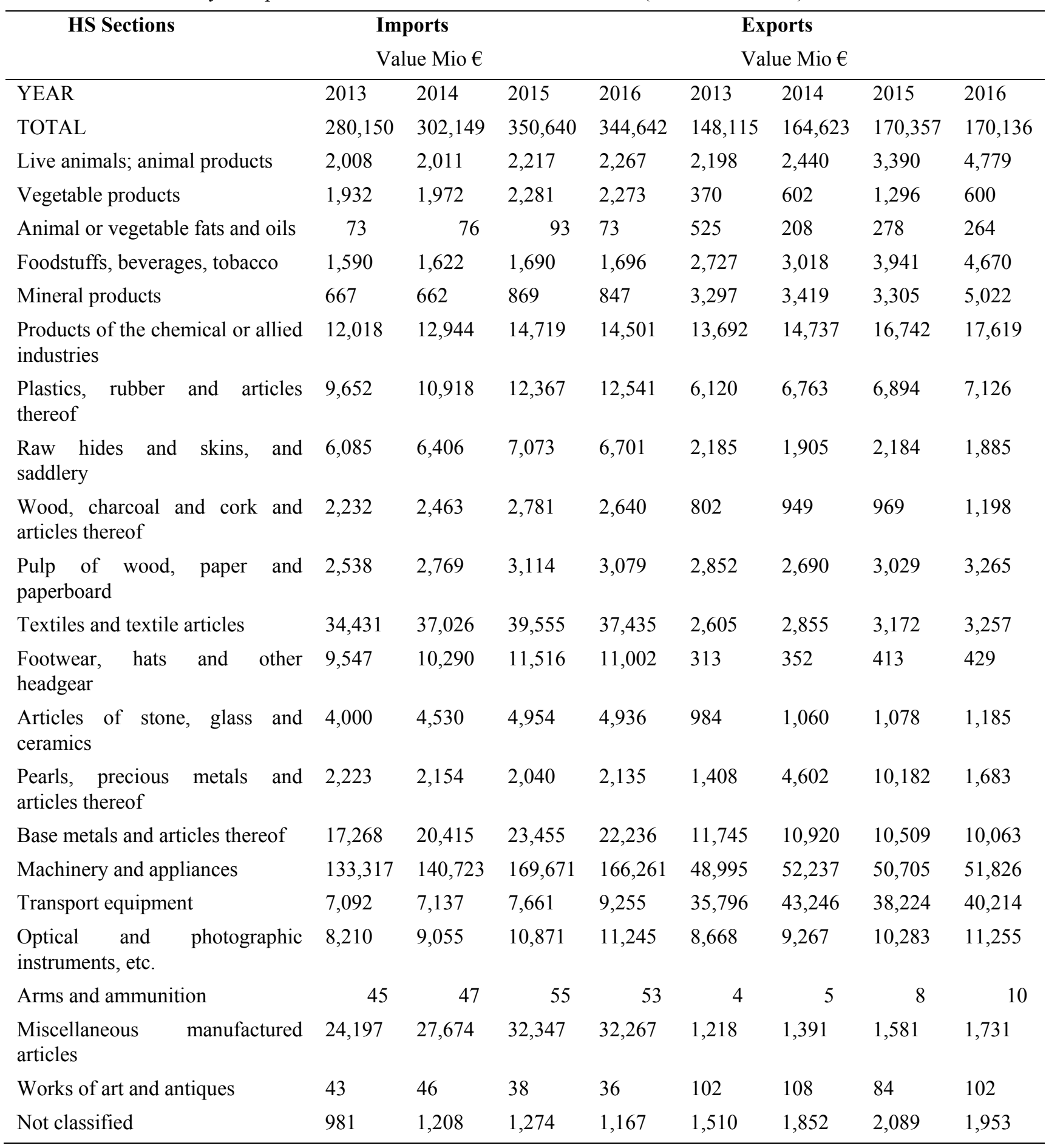

If we consider the imbalanced situation as for mutual trade between the European Union and china, and the train transportation between the two sides (most trains from China to Europe are coming back empty) then we can explore and propose some areas of cooperation which can be utilized by the European side to use the trains to export more items to china through these empty wagons.

With regard to the booming situation of the export of certain items from Europe to china such as live animal and animal products, food stuffs and beverages as well as tobacco, it can recognized that using the railway for the export of some of these items with encouraging market in china should be seriously considered by the European exporters.

On the other hand, investigating the reasons for the decrease of main exportable items from Europe to China such as machinery and appliances, transport equipment, optical and photographic instruments, peral and precious metals, we 
may find that replacing the train transportation instead of sea will cause to quicker access to the Chinese markets for some specific items which are time sensitive and can make more money for importers by saving time. This way, they will definitely be encouraged to substitute railway to import their items from Europe.

All in all, there are some exportable items from Europe to China which can be transported by railway rather than the sea despite the higher cost and with the following features and characteristics:

Table 8. Exportable items from Europe union to china which may benefited by train

Products category
They are Welcomed to china
market

Sensitive to arrival time

Sensitive to weather and humadity of sea and ocean

Sensitive to transportation means

Rate of value to transportation cost is very high

characteristics
Export of them is
booming from Europe to china
they should arrive to end users
as early as possible otherwise
the new models and fashion
will come quickly and old
fashion has lost their value

Humadity and wet of environment can make damage and its protection from wet and humidity make more extra packing cost

there are some kind of machineries and equipments which due to their sizes and dimensions should be transported in open top containers and sea transpiration will be several time higher for such items than transportation by normal container

some machineries and equipments has a big value compare to the transportation cost and even one day early arrival of them to the destination can make more money for importers by time saving

examples
as live animal and animal
products, food stuffs and
beverages as well as tobacco
cloth and dresses

beauty and cosmetic products

and construction machineries and equipments

High tech machineries and solar panel and energy oriented machineries and equipments

Considering the aforementioned features, it is proposed that high tech machinery and equipment, specially in road and construction, energy industry and solar energy, also auto parts and accessories, food stuff, beverage and wine, cosmetic and hygienic products and some fashion products such as clothing have more chances if transported by train from Europe to china.

\section{Discussion for Coping with the Challenges}

Firstly, concerning the cost issue, sea transportation cost is one third of block train transportation which takes place in 12 to 17 days 9 (average of 15 days) in comparison with 30 to 35 days done through the sea from China to Europe. Hence, most of the normal clients will choose sea way. Based on the survey did by of He Dan and Li Wenchao (2016) from Ningbo to Hamburg, companies only view the value 10 days reduction of delivery as 200 USD, and they are willing to take the rate of USD 2,200 instead of ordinary sea transportation rate as 2,000 USD (Tao, 2017). So, it can be perceived that the normal sea way users are not easy to shift to Block Trains, only those who value the time are likely to block train services. We think that the rate of block train from China to Europe could be further reduced to about $10-20 \%$, which is based on the Russian's Siberian Railway Rate. Generally speaking, Line Three (via Manzhouli) is longer than Line One (via Alashankou), 2,451 KM, and the relative lower rate in Line Three still can attract clients to use its services. Meanwhile, we may expect Line One to further reduce the cost to match that of Line Three. 
Secondly, the distance between European inner land stations is more suitable to connect Chinese block trains, which will be faster with no unloading and transit time lapse. Meanwhile, it is very important to decide on the most suitable return cargo for loading the containers. Nowadays, Chinese customers have an increasing demand for European agricultural, dairy and wine products, as well as portable drinking water. European producers and business people are encouraged to expand their business fields to those mentioned areas.

Thirdly, we know that the middle line via Mongolia has relatively fewer block trains passing owing to the single track, both in Inner Mongolia and Mongolia; therefore if the infrastructure of this Line is upgraded to double tracks, it will be of great advantage and it make new contribution to block trains from China to Europe.

Fourthly, we realized that the unbalanced railway cargo direction from Eastern Asia to Europe is not a new problem and has existed for decades. There aplenty of empty wagons and containers from Europe to Eastern Russian annually. Constructing special ships and wharfs will facility filling those empty wagon and containers which in turn will be a quite economic tactic for the Eastern Russian region. Russia is the only country which has got the advantage of filling the empty wagon and containers from St. Petersburg to Vladivostok.

Finally, considering the imbalanced situation in the trade between European union and china and the empty trains from Europe, it can be proposed that high tech machinery and equipment, specially to see for road and construction, energy industry and solar energy, and auto parts and accessories, food stuff and beverage and wine, cosmetic and hygienic products and some fashion products including clothings to be used to solve the problem of empty wagons and containers from Europe to China by means of train transportation.

\section{References}

He, D., \& Li, W. C. (2016). Measures on Sustainable Development of China Railway Express Driven by Port Cities, China Business and Market, October 2016, 30.

Huang, S. C. (2016). To develop national strategy to deal with China-Europe Block Train Multimodal Transportation Competitiveness, Science \& Technology Vision, 2016(1).(in Chinese)

Li, Z. Y. (2015). Constructing Sino-Europe Regular Cargo Train Brand to Form One Belt One Road Railway Transportation New Structure, Port Economy, December 2015 (in Chinese)

Oleg, B. (2016). The summary speech in the XI International Rail Business Forum Strategic Partnership 1520 in Sochi ended on 3 June, 2016, www.eng.rzd.ru

Peng, Q., \& Ma, J. (2016). Sino-Europe Regular Cargo Train Accumulated to 1500, the People's Railway of China, April 13, 2016, A01.

Tao, L. P. (2016). China Railway starts to use unified brand of China Railway Express to Sino-Europe-Freight Trains, China Youth Daily, June 11, 2016.

\section{Copyrights}

Copyright for this article is retained by the author(s), with first publication rights granted to the journal.

This is an open-access article distributed under the terms and conditions of the Creative Commons Attribution license which permits unrestricted use, distribution, and reproduction in any medium, provided the original work is properly cited. 